\title{
Endorser Sebagai Affirmative Action Dalam Komunikasi Bisnis
}

\author{
Priyo Dari Mulyo \\ Dosen Ilmu Komunikasi FISIP Universitas Merdeka Malang \\ Email: priyodarimulyo@unmer.ac.id
}

\begin{abstract}
The relevabce between business communications and marketing communications exist is in promotion. Activity is due to both activities related to the increase in profit or gain. Promotion is a middle way between business communication and marketing communication which is achieving the desired target. There is also a strategy that is considered as an act of reassurance to reach the target of endorser use on promotional activities in the media. Use of endorser is not so simple, because a lot of things that must be considered and taken into account in choosing the endorser that communication within the business running effectively and efficiently. Celebrity endorser and experts most suitable for use as a business communication strategy by considering the concept of TEARS.
\end{abstract}

Key words: Business Communication, Marketing Communications, Endorser, Affirmative Action.

\begin{abstract}
Abstrak
Benang merah dari komunikasi bisnis dan komunikasi pemasaran ada pada kegiatan promosi. Hal ini disebabkan kedua kegiatan tersebut berkaitan dengan peningkatan laba atau keuntungan. Promosi menjadi jalan tengah antara komunikasi bisnis dan komunikasi pemasaran untuk mencapai target yang diinginkan. Terdapat pula strategi yang dianggap sebagai tindakan peneguhan untuk mencapai target yakni penggunaan endorser pada kegiatan promosi di media massa. Penggunaan endorser tidak semudah yang dibayangkan, karena banyak hal yang harus diperhatikan dan dipertimbangkan dalam memilih endorser agar komunikasi bisnis berjalan efektif dan efisien. Endorser selebriti dan ahli yang paling cocok digunakan sebagai strategi komunikasi bisnis dengan mempertimbangkan konsep TEARS.
\end{abstract}

Kata Kunci: Komunikasi Bisnis, Komunikasi Pemasaran, Endorser, Affirmative Action.

\section{PENDAHULUAN}

Di era perdagangan bebas, kompetisi terbuka lebar antara pelaku bisnis. Kompetisi tersebut menjadi kendala dalam kegiatan bisnis, yang bisa diatasi dengan kegiatan komunikasi bisnis untuk menciptakan kondisi yang kondusif. Komunikasi bisnis merupakan salah satu wujud komunikasi yang berkonsentrasi pada aktivitas bisnis. Di dalam komunikasi bisnis sering kali melibatkan komunikasi antar 
pribadi, komunikasi organisasi sekaligus komunikasi pemasaran. Tujuan sederhana dari komunikasi bisnis adalah untuk menyampaikan pesan bisnis yang dibuat oleh komunikator kepada komunikannya. Aspek terpenting dalam proses komunikasi bisnis adalah aspek persuasi. Dengan kata lain dalam komunikasi bisnis membutuhkan peneguhan atau tidakan afirmasi (affirmative action) dalam mengemas pesan sekaligus untuk mempengaruhi khalayaknya.

Media massa merupakan salah satu komponen dalam komunikasi bisnis, dimana media massa berfungsi sebagai saluran yang menjadikan penghubung antara komunikator (produsen) dengan komunikan (konsumen). Praktik komunikasi bisnis yang terjadi dalam media massa selalu melibatkan pihak di luar produsennya yakni yang lebih dikenal dengan endorse. Definisi endorser adalah orang yang terlibat dalam proses komunikasi untuk melakukan penyampaian pesan pemasaran produk, dengan secara langsung ataupun tidak langsung. Di dalam produksi iklan, endorser berfungsi sebagai juru bicara agar merek sebuah produk cepat melekat pada konsumen. Tujuan akhirnya adalah supaya konsumen memiliki kemauan untuk membeli merek tersebut. (Royan, 2005:2)
Karena proses penyampaian pesannya berbeda-beda (langsung ataupun tidak langsung) maka efek dari penggunaan endorsenya pun demikian yakni disadari ataupun tidak disadari oleh khalayak. Penggunaan endorse dalam komunikasi bisnis membentuk sebuah proses yang akan terjadi antara produsen dengan khalayak, dengan output agar proses komunikasi bisnis mendapat perhatian yang besar disamping sangat mudah diingat oleh khalayak.

Seperti yang telah diungkap dalam penelitian yang dilakukan oleh Steven Agustinus Hansudoh di artikel yang berjudul Pengaruh Celebrity Endorsement Terhadap Purchase Intention Melalui Perceived Value. Dimana di dalamnya menjelaskan bahwa endorse memiliki pengaruh yamng besar dalam membentuk persepsi dan keinginan khalayaknya.

Berdasar paparan di atas, unsur persuasi yang terdapat dalam komunikasi bisnis bisa dilihat bahwa endorse bisa dijadikan sebagai kegiatan penegehuan (afirmasi) untuk memperlancar kegiatan komunikasi bisnis dan menghantarkannya menuju tujuan besar komunikator dalam komunikasi bisnis. Dari uraian pendahuluan di atas, terdapat rumusan permasalahan yang akan dibahas, yakni : bagaimana endorse 
digunakan sebagai peneguhan (afirmasi) dalam komunikasi bisnis.

\section{TINJAUAN PUSTAKA}

\section{Komunikasi Pemasaran dalam Komunikasi Bisnis}

\begin{abstract}
Komunikasi Bisnis merupakan pengembangan bentuk dari aktivitas komunikasi yang dilakukan oleh manusia. Definisi terkait komunikasi bisnis biasanya dikaitkan dengan definisi komunikasi secara umum. Dimana komunikasi secara umum merupakan proses berbagi makna melalui perilaku verbal maupun non verbal, yang biasanya melibatkan paling sedikit dua orang dengan melibatkan ekpektasi, persepsi, pilihan, tindakan serta penafsiran. (Mulyana, 2004 :3-7)
\end{abstract}

Sehingga secara singkat komunikasi bisnis dapat dimaknai sebagai aktivitas komunikasi yang digunakan dalam dunia bisnis, di dalamnya mencakup berbagai macam bentuk komunikasi baik komunikasi verbal maupun nonverbal. (Purwanto, 1997 : 1)

Sedangkan pengertian bisnis sendiri menurut Lawrence D. Brennan adalah " $a$ dynamic structure of interchanging ideas, feeling and cooperative effortsto get profit", dimana suatu struktur yang dinamis dari pertukaran gagasan, perasaan dan usaha bersama untuk mendapatkan keuntungan. (Priyatna \& Ardianto, 2009 : 24-25)

Dari paparan tersebut dapat dilihat bahwa tujuan dari komunikasi bisnis adalah untuk mencapai keuntungan baik berupa material maupun non material. Untuk mencapai tujuannya, komunikasi bisnis bisa dikolabirasikan dengan komunikasi pemasaran. Dimana komunikasi pemasaran merupakan strategi dari komunikasi bisnis yang melibatkan pihak lain di luar produsen (komunikator) dan konsumen (komunikan).

\begin{tabular}{|c|c|c|}
\hline Dalam & Effendy & $(2006$ \\
\hline komunikasi & merupakan & proses \\
\hline mengubah & perilaku & orang \\
\hline
\end{tabular}
(communication is the process to modify the bahavior of other individuals). Berdasarkan pendapat Houvland di atas, komunikasi bisnis memiliki fungsi utama untuk mengubah perilaku orang lain terhadap produk komunikasinya. Hal ini bisa dilakuan melalui komunikasi pemasaran.

Sedangkan pemasaran menurut Kottler \& Amstrong adalah kegiatan manusia yang di arahkan untuk memuaskan kebutuhan dan keinginan melalui proses pertukaran. (Kottler \& Amstrong, 1997 : 23) 
Penggabungan praktik komunikasi bisnis dengan komunikasi pemasaran disebut juga sebagai komunikasi pemasaran terpadu. Adapun kegitan dalam komunikasi pemasaran terpadu adalah berupa periklanan, penjualan personal, humas, promosi penjualan dan penjualan langsung. (Sulaksana, $2005: 24$ )

\section{Kesenjangan Dalam Komunikasi Bisnis}

\begin{abstract}
Kesulitan dalam berkomunikasi sering disebut sebagai hambatan komunikasi. Dalam komunikasi bisnis, kesenjangan ditinjau dari tiga aspek yakni linguistik, praktis dan budaya. Aspek linguistik ditinjau dari permasalahan kebahasaan, dimana perbedaan bahasa bisa menjadi kesenjangan. Aspek kedua adalah praktis yakni proses penerapan komunikasi bisnis. Sedangkan aspek budaya adalah latar belakang budaya yang berupa suku dan kebiasaan manusia dalam menerapkan komunikasi bisnis. (Lewis, 1996 : 98)
\end{abstract}

\section{Lewis (1996 : 126) berpendapat}

Solusi untuk mengatasi kesenjangan dalam komunikasi bisnis adalah menyentuh pada pola pikir khalayak dan komunikatornya. Salah satu cara yang dapat dilakukan adalah melalui negosiasi atau perundingan bisnis. Perundingan tersebut berujung pada keputusan. Dalam proses pengambilan keputusan endorse memiliki peranan penting untuk mengubah pola pikir khalayak terhadap suatu produk. Kekuatan endorse dapat dibentuk oleh komunikator (produsen) yang disesuaikan dengan jenis produk. Komunikasi bisnis merupakan saluran yang dapat mendorong peranan endorse menjadi peneguh (afirmasi) dalam kegiatan bisnis.

\section{Endorse Dalam Komunikasi Bisnis}

Alat pendukung yang digunakan dalam periklanan untuk tujuan pemasaran suatu produk disebut endorser. Dengan kata lain Endorser merupakan simbol yang juga disebut sebagai sumber langsung (directsource) yang memiliki fungsi mendistribusikan pesan dan atau meperagakan produk atau jasa dalam kegiatan promosi. Tujuan dari kegiatan tersebut adalah untuk mendukung efektifitas penyampaian pesan produk atau jasa tersebut. (Belch \& Belch, 2004:168).

Hal ini didukung oleh pendapat Sutisna (2003 : 272) penggunaan opinion leader merupakan cara yang efektif dalam pemasaran. Hal ini dikerenakan kecenderungan manusia dalam meniru manusia lainnya yang mereka anggap lebih dari dirinya. 
Menurut Shimp (2002) terdapat empat jenis endorser yang digunakan dalam komunikasi bisnis, yaitu :

a. Celebrity endorser. Selebritis adalah orang-orang yang terkenal oleh masyarakat secara luas baik itu bintang film, penyanyi, pelawak, atlit, model.

b. Expert endorser, bintang iklan yang memiliki pengetahuan dan kemampuan dalam bidang tertentu.

c. Lay endorser, merupakan bintang iklan non selebritis.

d. Dead endorser adalah bintang iklan orang/tokoh yang telah meninggal dunia.

Shimp (2002) menjelaskan pula bahwa jenis endorser memiliki karakteristik dan atribut yang sama hanya dibedakan dalam penggunaan orang-orangnya sebagai pendukung, apakah orang-orang yang digunakan sebagai endorser tokoh terkenal atau tidak.

\section{METODE PENELITIAN}

Penelitian ini menggunakan metode studi literatur dengan mencari referensi teori yang relefan dengan kasus atau permasalahan yang ditemukan. Referensi teori yang diperoleh dengan jalan penelitian studi literatur dijadikan sebagai fondasi dasar. Penulis menggunakan data primer dengan melakukan obervasi dan data sekunder yaitu data yang diperoleh dari jurnal, buku dokumentasi, dan internet.

Dokumentasi merupakan metode untuk mencari data-data yang dianggap penting melalui artikel koran/majalah, jurnal, pustaka, brosur, buku dokumentasi serta melalui media elektronik yaitu internet, yang memiliki keterkaitan dengan penelitian ini.

Studi literatur merupakan metode yang dipakai penulis dengan cara menghimpun data maupun sumber yang berhubungan dengan topik yang diangkat dalam suatu penelitian. Sumber yang digunakan berupa jurnal, buku, serta artikel ilmiah. Observasi langsung dilakukan dengan cara pengambilan data menggunakan mata tanpa ada pertolongan alat standar lain untuk keperluan tersebut yakni melihat fenomena yang berkaitan dengan topik penelitian ini.

Metode deskriptif yang digunakan dalam penelitian ini dilakukan dengan cara menggambarkan fakta-fakta yang didapat kemudian dilakukan analisis. Proses deskripsi yang terjadi tidak hanya melakukan penguaraian data dan fakta, 
melainkan juga memberikan pemahaman dan penjelasan atas kesesuaian maupun kejanggalan fenomena dan literatur yang ditemukan.

Gambar Kerangka Berpikir Penggunaan Endorser

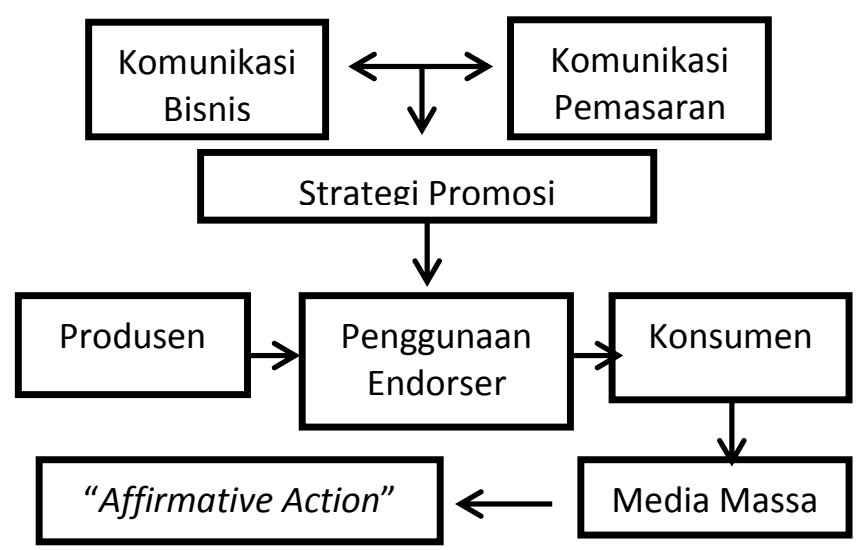

Sumber : diolah oleh peneliti

\section{HASIL DAN PEMBAHASAN}

\section{Penggunaan Endorser sebagai Affirmative Action}

Komunikasi bisnis sering kali dianggap sebagai solusi awal di dalam permasalahan bisnis. Namun, komunikasi pemasaran dianggap sebagai ujung tombak dalam menyelesaikan permasalahan dalam komunikasi bisnis. Sehingga dalam implementasinya komunikasi bisnis dapat digabungkan dengan komunikasi pemasaran untuk mencapai tujuan bisnis yang seutuhnya.
Tujuan yang ingin diraih dalam komunikasi bisnis maupun komunikasi pemasaran adalah keuntungan bagi produsen dan kepuasan bagi konsumen. Keuntungan bukanlah merupakan tujuan akhir, akan tetapi keberlanjutan (suistanibility) proses produksi dan distribusi merupakan tujuan akhirnya. Hal ini dikarenakan supaya kegiatan bisnis akan terus berkelanjutan dan memiliki usia yang sangat panjang.

Dalam mengembangkan kegiatan bisnis atau perdagangan, strategi yang bisa digunakan dari menggabungkan antara komunikasi bisnis dengan komunikasi pemasaran adalah berupa strategi promosi. Promosi dilakukan untuk meningkatkan kekuatan produsen dalam melakukan persuasi konsumen. Tujuan akhirnya adalah meningkatkan permintaan produk atau jasa yang disediakan produsen. Terlebih lagi, promosi digunakan untuk menarik konsumen baru dan mempertahankan konsumen baru menjadi konsumen tetap.

Dalam melakukan kegiatan promosi harus memperhatikan banyak aspek. Jika ditinjau dari segi komunikasi bisnis terdapat empat aspek dasar dalam penerapannya, yakni produsen, pesan, media serta konsumen. Keempat aspek tersebut akan mempengaruhi efek penyampaian pesan dari produsen kepada konsumen. Distribusi 
pesan biasanya menggunakan bantuan media massa.

Pembuatan pesan yang dilakukan oleh produsen merupakan langkah awal yang menentukan tercapai tidaknya tujuan komunikasi bisnis. Proses pembuatan pesan dipengaruhi oleh pengalaman komunikator (field of experience) serta kerangka acuan atau berpikir (frame of reference). Singkronisasi keduanya akan membawa produsen pada terbentuknya pesan yang efektik untuk mempengaruhi konsumen yang hendak disasarnya.

Sedangkan pesan yang dibentuk juga disesuaikan dengan kondisi serta latar belakang dari konsumen yang hendak disasar. Segmentasi pasar juga menjadi faktor penentu dalam distribusi pesan komunikasi bisnis.

Setelah pesan, media massa merupakan faktor selanjutnya yang menjadi penentu efektifnya sebuah kegiatan komunikasi bisnis. Media massa merupakan channel atau saluran yang digunakan untuk menyalurkan pesan yang sudah diciptakan untuk memiliki dampak atau efek yang sebarannya cukup luas. Dalam menggunakan media massa juga harus memperhatikan segmentasi atau sebaran audiens yang menggunakan media massa tersebut. Hal ini dilakukan agar proses penyampaian pesan yang melalui media massa menjadi efektif.

Media massa memiliki audiens yang heterogen dengan sebaran yang anonim. Artinya bahwa bisa dipastikan audiens yang menggunakan media massamemiliki motif yang berbeda. Namun, yang bisa menyatukan motif dan pola dari audiens adalah berupa endorser. Endorser merupakan pendukung dalam sebuah iklan yang mampu mempengaruhi audiens.Hal ini biasanya terjadi karena endorser bisa berwujud selebriti atau orang yang sudah populer dan dikenal oleh audiens.

Endorser tidak selamanya memiliki pengaruh yang signifikan terhadap perspektif dan minat audiens. Hal ini tergantung pada ketepatan dan kecermatan dalam memilih dan menggunakan endorser sebagai pendukung sebuah iklan dalam mempengaruhi dan mendapatkan perhatian audiens (konsumen).

Senada dengan penjelasan Shimp (2003) bahwa strategi pemasaran yang tepat adalah menggunakan endorser. Penggunaan endorser yang berupa orang populer atau selebriti sering kali dikenal dengan istilah Celebrity endorser. Dimana endorser ini dipilih karena prestasi, popularitas bahkan reputasinya. 
Endorse difungsikan sebagai stimulan yang memberikan impresi atas pesan yang disampaikan bisa dipercaya oleh audiens. Oleh karenanya dalam menggunakan endorser, selebriti bukan satusatunya jenis endorse yang bisa digunakan untuk membentuk persepsi hingga mempengaruhi persepsi audiens. Cara lain yang bisa digunakan dalam memanfaatkan endorser adalah melalui melakukan indentifikasi atas Typical person endorser. Artinya bahwa menggunakan orang yang bukan berasal dari kalangan selebritis untuk dijadikan sebagai endorser. Seperti misalnya produsen menggunakan testimoni para konsumenyang memiliki pengalaman dalam menggunakan produknya. Hal ini menjadi sangat efektif karena testimoni dari endorse memberikan peneguhan atau memperkuat alasan atas penggunaan barang maupun jasa yang dipasarkan.

Endorser yang bukan berasar dari kalangan selebriti tersebut sering kali dinamai sebagai lay endorser. Jika dibandingkan dengan celebrity endorser,lay endorser lebih ekonomis. Karena endorser non selebriti ini dianggap relatif tidak mengeluarkan biaya yang banyak.Namun, keunggulan dari lay endorser adalah pernyataan (testimony) dari masyarakat awam yang seolah-olah tanpa konstuksi pesan. Artinya bahwa ini dijadikan sebagi peneguhan kepada audiens lainnya terkait produk atau jasa yang diiklankan.

Pertimbangan utama iklan yang menggunakan dead endorser berupa daya tarik dan kredibilitas sebuah pesan. Penggunaan kredibilitas untuk meyakinkan audiensnya. Peneguhan muncul dari proses mengenang dead endorser. Cara kerjanya hampir sama dengan celebrity endorser, namun yang membedakan dead endorser adalah orang yang sudah meninggal, bisa seorang selebriti ataupun tokoh terkenal selain selebriti.

Berbeda lagi dengan expert endorser, yaitu ahli atau pemimpin pendapat yang digunakan dalam membantu menyampaikan pesan melalui iklan di media massa. Ahli atau pemimpin pendapat adalah orang-orang yang pendapatnya mengenai suatu produk tertentu dituruti oleh orangorang yang kurang tahu tentang produk tersebut. Expert endorser mempunyai peran yang penting dalam komunikasi dari mulut ke mulut. Pemasar mengetahui data para ahli atau pemimpin pendapat ini dari daftar nama dan alamat orang-orang yang pernah menanyakan melalui surat tentang suatu produk di masa yang lampau. Biasanya, orang-orang tersebut bertipe inovator. 
Expert endorser bisa digunakan karena mereka memiliki pengalaman dan kompetensi untuk merasionalisasikan keunggulan sebiah oroduk atau jasa. Alasan mpaikan pesan pemasar atau produsen menggunakan endorses dijadikan sebagi peneguhan atas produk atau jasa mereka adalah mereka memiliki kekammpuan untuk memahami individu ataupun khalayak yang sedang mereka hadapi. Expert endorser dan celebrity endorse tergolong sebagai endorser yang membutuhkan biaya tinggi. Hal ini dikarenakan kompetensi dari individu yang digunakan sebagai endorser.

Affirmative action yang dimaksud adalah sebagai tindakan peneguhan untuk bisa memberikan gambaran, merubah persepsi bahkan mempengaruhi khalayak. Melalui empat jenis endorser yang sering digunakan di Indonesia adalah celebrity endorse. Artis atau selebritis masih dipandang memiliki derajat yang tinggi. Kepopuleran selebriti menjadi komoditas dalam peneguhan produk atau jasa yang diiklankan. Masyarakat Indonesia masih menggunakan media mainstream berupa televis juga menjadi penyebab tingginya penggunaan selebriti untuk mempromosikan sebuah produk atau jasa. Kecenderungan fungsi hiburan dalam masyarakat juga menjadikan selebriti sebagai alat pembantu utama dalam mempromosikan sesuatu melalui media massa.

Dari keempat endorser yang paling sering dipakai dalam komunikasi bisnis adalah celebrity endorser. Hal ini dikarenkan aspek ketenaran selebriti menjadi komoditas tersendiri dalam menyampaikan pesan secara efektif. Faktor yang menjadi penentu keberhasilan endorser selebritis adalah kesesuaian antara produk dengan selebriti yang digunakan dalam kegiatan promosi. Kesesuainan itu bias dilihat dari segi usia, dan latar belakang dari selebriti yang menjadi endorse produk tersebut. Faktor kedua, kesesuaian antara selebriti dengan segmentasi pasar atau targer audiens, dimana keduanya harus memiliki kesamaan tujuan dan latar belakang. Faktor ketiga, tingkat kepopuleran dan kredibilitas selebriti. Popularitas berbanding lurus dengan kredibilitas jika ingin menggunakan selebriti sebagai endorser.

\section{Atribut Endorser dalam Affirmative Action}

Shimp (2003:304) menggolongkan endorser menjadi dua atribut umum dan lima atribut khusus untuk memfasilitasi serta menciptakan efektivitas dalam komunikasi bisnis. Secara spesifik mengatakan : 
"Extensive reaserch has demonstrated that two general attributes, credibility and actractiveness, contribute to an endorser's effectiveness and that each consists of more distinct subatributes...we use tha acronym TEARS to represent five discrete attributes: trustworthiness and expertise are two dimensions of credibility, whereas phsycal attractiveness, respect and similarity (to target audience) are components of the general concept of attractiveness".

Terdapat lima atribut khusus untuk endorser dijelaskan dengan akronim TEARS. Terdapat dua dimensi untuk menentukan selebriti dan ketertarikan fisik, tanggapan, kesenangan merupakan komponen dari konsep umum ketertarikan. Konsep TEARS tersebut dapat dijelaskan sebagai berikut :

\section{Trustworthiness (dapat dipercaya)}

Sikap percaya dari pencitraan suatu pendukung produk merupakan kunci utama dalam penggunaan endorser. Hal ini berkaitan dengan tingkat kejujuran, ketulusan, dan kredibilitas sumber yang dijadikan sebagai endorser. Dengan demikian endorser memiliki kemampuan untuk menarik perhatian sekaligus dapat membuat audiens memiliki kepercayaan terhadap tindakan maupun perkataan endorser. Aspek penting yang diutamakan dalam penggunaan endorser ahli adalah kemampuan untuk memberi kepercayaan pada audiens yang disasar sebagai calon konsumen suatu produk.

Trustworthiness memiliki beberapa indikator dalam menciptakan atau menghantarkan tujuan komunikasi bisnis.

a. Kejujuran adalah mengakui, berkata atau memberikan suatu informasi yang sesuai kenyataan dan kebenaran.

b. Ketulusan adalah sebuah kesediaan malakukan tugas dengan penuh tanggung jawab.

c. Dapat di percaya yaitu memiliki integritas dan kredibilitas dalam menyampaikan pesannya.

\section{Expertise (keahlian)}

Shimp (2003:205) menjelaskan bahwa keahlian (expertise) mengacu pada pengetahuan, pengalaman atau keahlian yang dimiliki oleh seorang endorser yang dihubungkan dengan merek yang didukung. Expertise merupakan competitive advantage yang dimiliki pendukung untuk meyakinkan serta untuk memperteguh audiensdalam hal keterampilannya. Indikator yang digunakan untuk melihat keahlian endorser antara lain berupa : pengetahuan (frame of reference), pengalaman (field of experience), keahlian (expert).

3. Attractiveness (daya tarik) 
Shimp (2003:304-305) menjelaskan bahwa attractiveness atau yang dikenal dengan daya tarik mengacu pada diri yang dianggap sebagai yang menarik untuk dilihat dalam kaitannya dengan konsep kelompok tertentu dengan daya tarik fisik. Pemilih menemukan sesuatu pada diri endorser yang dia sukai maka bujukan bekerja lewat identifikasi. Artinya, lewat identifikasi, pemilih akan mengadopsi perilaku, sikap atau preferensi. Ketika mereka menemukan hal menarik dalam diriendoser.

Endorser dengan tampilan fisik yang baik dan/atau karakter non-fisik yang menarik dapat menunjang iklan dan dapat menimbulkan naiknya minat audiens untuk menyimak iklan. (Belch dan Belch, 2004)

\section{Respect (kualitas dihargai)}

Respect diartikan sebagai kegiatan pemberian penghargaan dari audiens terhadap suatu produk setelah melihat dan mendengar informasi dari endoerser. Shimp (2007:306) menjelaskan respect (kualitas dihargai) berarti kualitas yang dihargai atau digemari sebagai akibat dari kualitas pencapaian personal. Penghargaan adalah sebuah bentuk apresiasi kepada suatu prestasi tertentu yang diberikan baik oleh perorangan ataupun suatu lembaga. Selebritas dihargai karena kemampuan akting mereka, keterampilan berolahraga atau kepribadian dan kualitas argumentasi politiknya. Individu yang dihargai juga secara umum disukai, dan hal ini dapat digunakan untuk meningkatkan ekuitas merk.

5. Similarity (kesamaan dengan audiens yang dituju)

Shimp (2007:306) menjelaskan bahwa similarity (kesamaan dengan audiens yang dituju) merupakan kesamaan dengan audiens yang dituju (similarity) mengacu pada kesamaan antar endorser dan audiens dalam hal umur, gender, etnis, status sosial dan sebagainya. Hal ini dipertegas oleh Belch dan Belch (2004) yang menyatakan bahwa similarity, merupakan persepsi khalayak berkenaan dengan kesamaan yang dimilik endorser, kemiripan ini dapat berupa karakteristik demografis, gaya hidup, kepribadian, masalah yang dihadapi sebagaimana yang ditampilkan pada iklan dan sebagainya.

\section{KESIMPULAN}

Kesimpulan yang dapat diambil adalah sebagai berikut :

1. Dalam komunikasi bisnis dimungkinkan menggunakan strategi komunikasi pemasaran. Hal ini 
dikarenakan komunikasi bisnis memliki relevansi dengan komunikasi pemasaran. Letak persamaan antara komunikasi bisnis dengan komunikasi massa dalam penelitian ini adalah ada pada strategi promosi. Strategi promosi yang menggunakan media massa memiliki kekuatan untuk mempengaruhi audiens calon konsumen maupun konsumen tetap.

2. Dalam strategi promosi endorser dipilih untuk menjadi strategi utama dalam menciptakan komunikasi bisnis yag efektif. Endorser sekaligus menjadi simbol atas pesan yang akan disampaikan. Sehingga dalam memilih endorser harus berdasarkan kriteria dan memperhatikan jenis endorser.

3. Pemilihan penggunaan endorser disesuaikan dengan kebutuhan pemasar atau produsen dalam menyampaikan atau mempromosikan produk ataupun jasa yang akan dipasarkan. Sekaligus melihat segmentasi pasar yang hendak disasar.

4. Celebrity Endorser dan Expert Endorser menjadi jenis endorser yang paling sering digunakan pengiklan atau pemasar dalam mempengaruhi bahkan mengubah persepsi audiens media massa. Hal ini dikarenkan keduanya memiliki unsur trustworthiness (dapat dipercaya), expertise (keahlian), respect (kualitas dihargai), serta similarity (kesamaan dari audiens yang disasar).

5. Faktor utama yang harus diperhatikan dalam memilih selebriti sebagai endorser adalah kesesuaian antara produk dengan slebriti yang dipilih, kesesuaian antara selebriti dengan target audiensnya, serta tingkat kepopularitasan dan kredibilitas selebriti.

6. Berdasar pada kelima unsur pendorong penggunaan endorser, maka endorser dianggap sebagai kegiatan yang mampu meneguhkan atau memperkuat proses komunikasi bisnis menjadi lebih efektif (affirmative action). Dianggap sebagai affirmative action, karena endorser melibatkan semua kemampuan komunikator dalam menyampaikan pesan untuk tujuan akhir mempengaruhi bahkan merubah perspektif audiens terhadap suatu produk maupun jasa. 


\section{REFERENSI}

Arikunto, 2005,Manajemen Penelitian, Rineka Cipta, Jakarta.

Belch, George \& Belch, Michael A, 2004, Advertising and Promotion : An Integrated Marketing Communication Perspective, Mc graw Hill Companies, New York.

Effendy, O. U, 2011,Ilmu Komunikasi Teori dan Praktek, Remaja Rosdakarya, Bandung.

Hansudoh, Steven Agustinus, 2013, Pengaruh Celebrity Endorsement Terhadap Purchase Intention Melalui Perceived Value Pada Produk Top Coffee Di Surabaya di download pada situ:http://download.portalgaruda.org/a rticle.php?article $=114002 \& \mathrm{val}=5209$ 29 desember 2016 pdf.

Hudori, 2010, Analisis Persepsi Konsumen Terhadap Endorser Iklan di Televisi dan Hubungannya dengan Keputusan Pembelian, Fakultas Ekonomi Institut Pertanian Bogor.

Kotler, Philip \& Amstrong, Gary, 1997, Prisip-Prinsip Pemasaran, Erlangga, Jakarta.

Kriyantono, Rachmat, 2012, Teknik Praktis Riset Komunikasi, Kencana, Jakarta.
Liliweri, Alo, 2009, Makna Budaya Dalam KomunikasiAntarbudaya, LKIS, Yogyakarta.

Moleong, Lexy J, 2012, Metode Penelitian Kualitatif, Remaja Rosdakarya, Bandung.

Mulyana, Deddy, 2010, Komunikasi Bisnis Lintas Budaya, RosdaKarya, Bandung.

Mulyana, Deddy, 2004, Komunikasi efektif : Suatu pendekatan Lintas Budaya, PT. Remaja Rosdakarya, Bandung.

Priyatna, Soeganda, 2009, Tujuh Pilar Strategi Komunikasi Bisnis, Widya Padjadjaran, Bandung.

Purwanto, Djoko, 2006, Komunikasi Bisnis, Erlangga, Jakarta.

Royan, Frans.M., 2005, Marketing Celebrities. Jilid 1, Elex Media Komputindo, Jakarta.

Shimp, Terence A., 2003, Periklanan Promosi.Jilid 1, Penerbit Erlangga, Jakarta.

Sutisna, 2002, Perilaku Konsumen dan Komunikasi Pemasaran. Cetakan Kedua, PT. Remaja Rosdakarya, Bandung. 